\title{
Pesquisa da Resistência Antimicrobiana de Escherichia coli Patogênica Extraintestinal (ExPEC) em Adubo Orgânico de Origem Aviária da Região de Londrina-PR
}

Luis Eduardo de Souza Gazal (I), Juan Josue Puño-Sarmiento (I), Leonardo Pinto Medeiros (I), Vanessa Lumi Koga (I), Renata Katsuko Takayama Kobayashi (I), Gerson Nakazato (I)

(I) UEL - Universidade Estadual de Londrina (Rodovia Celso Garcia Cid | Pr 445 Km 380 / Cx. Postal 10.011 | CEP 86.057-970 )

\section{Resumo}

A indústria avícola no Brasil é um dos setores que mais cresceram nos últimos anos, atingindo o terceiro lugar no ranking de produção mundial. Como resultado dessa massiva produção, uma grande quantidade de resíduos, como a cama de frango, são gerados todos os anos. Em virtude da quantidade de resíduos gerados na produção avícola, uma alternativa encontrada para o seu aproveitamento é sua utilização como adubo orgânico em plantações, como a de hortaliças. Entretanto, para que esse resíduo seja utilizado como adubo orgânico, este deve passar por um processo de compostagem para eliminar possíveis contaminantes biológicos, como bactérias patogênicas. Escherichia coli é um bacilo Gramnegativo que é encontrado na microbiota intestinal humana e de outros animais de sangue quente. Esta bactéria além de causar doenças intestinais como diarreias, pode causar doenças extraintestinais como septicemia, meningite e infecções urinárias e portanto são denominadas E. coli patogênica extraintestinais (ExPEC). É de conhecimento que na avicultura muitos antimicrobianos são utilizados como promotores de crescimento em frangos, além de servir como medida profilática. A transferência de genes de resistência para bactérias da microbiota intestinal humana é hoje uma

\footnotetext{
Referência:

Luis Eduardo de Souza Gazal, Juan Josue Puño-Sarmiento, Leonardo Pinto Medeiros, Vanessa Lumi Koga, Renata Katsuko Takayama Kobayashi, Gerson Nakazato. Pesquisa da Resistência Antimicrobiana de Escherichia coli Patogênica Extraintestinal (ExPEC) em Adubo Orgânico de Origem Aviária da Região de Londrina-PR. In: Anais do 12ㅇ Congresso Latinoamericano de Microbiologia e Higiene de Alimentos - MICROAL 2014 [= Blucher Food Science Proceedings, num.1, vol.1]. São Paulo: Editora Blucher, 2014. DOI 10.5151/foodsci-microal-336
} 
das maiores preocupações da saúde pública mundial. Dessa forma, o presente trabalho teve como objetivo isolar ExPEC de adubo orgânico de origem aviária e investigar a presença de resistência aos antimicrobianos. Amostras de adubo orgânico foram coletados em aviários e hortas da região de Londrina-PR, e imediatamente semeados em meio seletivo-diferencial ágar MacConkey para isolamento e posterior identificação de E. coli através de provas bioquímicas para enterobactérias. Após a identificação, as amostras foram testadas para diversas classes de antimicrobianos, como $\beta$-lactâmicos, aminoglicosídeos, tetraciclinas, macrolídeos, polipeptídeos, quinolonas e outros, pelo método de disco difusão em ágar. Foram isoladas 64 colônias de E. coli e todas foram testadas para 17 antimicrobianos. Das 64 colônias 53 eram resistentes a pelo menos um antimicrobiano, sendo as maiores resistências relacionadas à Amoxicilina (66\%), Ampicilina (49\%), Tetraciclina (43\%), Ácido Nalidíxico (43\%) e Estreptomicina (30\%). Todas as amostras foram sensíveis à Cloranfenicol, Enrofloxacina, Norfloxacina, Ciprofloxacina e Cefotaxima. Mesmo que não elevado, a presença de amostras resistentes a antimicrobianos nos alertam sobre o possível uso indiscriminado destes na avicultura, o que pode acarretar em seleção de cepas cada vez mais resistentes.

Palavras-Chave: ExPEC, antimicrobianos, resistência, adubo orgânico Agência de Fomento: $\mathrm{CNPq}$ 